\title{
O salário na obra de Frederick Winslow Taylor ${ }^{1}$
}

\author{
Victor Paulo Gomes da Silva ${ }^{2}$
}

\section{Resumo}

O presente artigo analisa e explica a perspectiva de Frederick Winslow Taylor sobre o salário, tal como enunciada em suas duas grandes obras: Shop management (1903) e Principles of scientific management (1911). A primeira parte consubstancia-se na apresentação de aspectos econômicos relevantes que caracterizaram o tempo em que ele viveu e o quanto influenciaram suas obras. $\mathrm{Na}$ segunda parte, é efetuada uma análise da forma como o salário é apresentado nas duas obras de F. W. Taylor. O artigo termina com um comentário sobre as obras supracitadas no que se refere à perspectiva taylorista do salário.

Palavras-chave: Salário; Custo de Produção; Produtividade; Trabalho; Taylor, Frederick Winslow, 1856-1915.

\begin{abstract}
Frederick Winslow Taylor's oeuvre: an analysis of wages

This paper analyses and explains Frederick Winslow Taylor's perspective on wages, as it is presented in his main literary works: Shop management (1903) and Principles of scientific management (1911). The first part presents the main economic aspects that characterized his lifetime, which undoubtedly influenced his literary works. The second part analyses F. W. Taylor's two main books in which the author's perspective about wages is discussed. The paper concludes with a critical view of F. W. Taylor's view on wages.
\end{abstract}

Keywords: Wages; Production cost; Productivity; Work; Taylor, Frederick Winslow, 1856-1915. JEL B31.

\section{Enquadramento histórico}

Frederick Winslow Taylor nasceu em 1856 e faleceu em 1915, na Filadélfia. Sua vida decorreu paralelamente a substanciais alterações na economia dos EUA e de outros países onde o sistema capitalista havia atingido maior desenvolvimento.

\subsection{Redução dos custos de produção}

O último quartel do século XIX - que se iniciou quando F. W. Taylor tinha 19 anos - foi dominado por um esforço acrescido dos dirigentes empresariais com vista a reduzir os custos de produção. Com essa finalidade, verificaram-se:

(1) Trabalho recebido em 17 de outubro de 2008 e aprovado em 4 de março de 2010.

(2) Professor Auxiliar da Universidade Aberta - Lisboa, Portugal. E-mail: victor@univ-ab.pt.

Economia e Sociedade, Campinas, v. 20, n. 2 (42), p. 397-415, ago. 2011. 
(1) Substanciais desenvolvimentos técnicos;

(2) Significativa concentração empresarial na indústria ${ }^{3}$;

(3) Estudos sobre tempos e movimentos das tarefas laborais, visando ao aumento da produtividade ${ }^{4}$.

Em relação ao primeiro aspecto - o desenvolvimento da técnica - o último quartel do século XIX e os primeiros anos do século XX presenciaram a Segunda Revolução Industrial: o petróleo e a electricidade tornaram-se fontes energéticas eficientes; surgiu a lâmpada elétrica; surgiram os motores a gasolina e diesel; desenvolveram-se as indústrias química e siderúrgica a tal ponto que a produção de aço tornou-se o ex libris da Segunda Revolução Industrial; nasceu o sistema Marconi de transmissão sem fios; desenvolveu-se imenso o transporte ferroviário, o que teve um impacto extremamente relevante no desenvolvimento das indústrias siderúrgica, metalúrgica e mecânica; surgiu o automóvel ${ }^{5}$; triunfou definitivamente a navegação a vapor e a construção de navios com estrutura metálica.

Os desenvolvimentos técnicos viabilizaram a formação da economiamundo em que atualmente vivemos, ou seja, as relações econômicas entre os diferentes espaços do Planeta assumiram uma intensidade e continuidade que permitiram afirmar a existência de uma integração econômica mundial.

Adicionalmente, nos países em que o sistema capitalista havia atingido maior desenvolvimento, o último quartel do século XIX e os primeiros anos do século XX até o início da Primeira Guerra Mundial caracterizaram-se por um processo de significativa concentração empresarial na indústria, quer em uma perspectiva vertical quer em uma perspectiva horizontal, possibilitando a obtenção de relevantes economias de escala.

Os setores industriais apareceram dominados por grandes empresas, tornando-se oligopolistas ${ }^{6} \mathrm{e}$, de forma tendencial, monopolistas. Tipicamente, para essas empresas serem grandes, exigiu-se a mobilização da poupança de muitos aforradores - já não eram empresas individuais ou familiares, mas sociedades por

(3) Por concentração industrial entende-se a aglutinação de uma percentagem cada vez maior do capital e da produção industriais em uma percentagem cada vez menor de grandes grupos empresariais. Em contrapartida, as pequenas e médias empresas, embora possam continuar a proliferar, representam uma percentagem cada vez menor do capital e da produção industriais. Frequentemente, até, essas empresas apenas sobrevivem graças às encomendas provenientes dos grandes grupos empresariais.

(4) A produtividade mede-se pela quantidade de bens ou serviços úteis (aptos a satisfazer necessidades humanas) produzidos por um trabalhador em uma unidade de tempo. Por seu turno, a intensidade mede-se pelo desgaste físico e psicológico verificado pelo trabalhador nessa unidade de tempo.

(5) Antes da Primeira Guerra Mundial, a indústria automóvel já havia assumido dimensão significativa.

(6) O termo é utilizado devido a seu poder expressivo e sem qualquer pretensão de rigor face à utilização do mesmo na teoria microeconômica. 
ações. Por seu turno, a dimensão do equipamento produtivo assumiu uma relevância desconhecida até então na história da indústria.

A concentração empresarial foi dinamizada pelo desenvolvimento dos bancos, que facilitaram à indústria o capital necessário a tal processo de concentração, tornando-se, além disso, detentores de capital e dirigentes de empresas industriais.

No caso dos EUA, essa concentração foi, também, dinamizada pelo próprio gigantismo dos projetos, decorrente do substancial volume das riquezas a serem exploradas.

\subsection{Os EUA}

Antes da Primeira Guerra Mundial, os EUA já eram a principal potência econômica do Mundo. O principal contributo para esse acréscimo de protagonismo econômico no último quartel do século XIX e início do século XX veio da produção industrial, nomeadamente das produções siderúrgica, metalúrgica, mecânica e elétrica.

O crescimento da produção dos EUA gerou aumento na procura de trabalhadores que não foi compensado pela oferta, provocando escassez de mão de obra. Adicionalmente, a concentração empresarial na indústria acarretou a mobilização, sob a mesma direção, de quantidades enormes - face ao passado - de trabalhadores. Essa concentração desenvolveu, portanto, consciência de classe nos trabalhadores e, por decorrência, a ação sindical e de partidos políticos ligados ao proletariado (essencialmente, industrial). Com a escassez de mão de obra e o desenvolvimento da consciência de classe aumentou o poder social dos trabalhadores.

Como consequência do aumento de poder social dos trabalhadores, verificou-se uma subida dos salários reais no último quartel do século XIX e início do século XX, que não se limitou à indústria, abrangendo também a agricultura e a pecuária. Essa subida contribuiu para que os EUA se tornassem um país de forte imigração origináriaessencialmente da Europa. Assim, entre 1860 e 1913, emigraram para os EUA mais de 26 milhões de europeus, dando uma substancial contribuição ao acréscimo da força de trabalho norte-americana. De tais imigrantes, uma percentagem muito significativa havia saído do meio rural, nomeadamente no caso dos provenientes da Europa meridional e oriental, portanto sem qualquer experiência de trabalho em meio industrial.

Como consequência do aumento de poder social dos trabalhadores, também se tornou insustentável manter os horários de trabalho tradicionais, manifestando-se a tendência de reduzi-los a oito horas diárias. Em 1868, isso já 
havia sido adotado nas empresas do Estado e, em 1906, em trinta e um estados dos EUA também já existiam leis fixando a duração diária do trabalho em oito horas.

A subida dos salários reais e a redução dos horários de trabalho suscitaram um esforço significativo, por parte dos dirigentes empresariais norte-americanos, de acréscimo da produtividade. Como não era possível conter o salário real nem sequer manter o horário de trabalho, então, que se aumentasse a produção efetuada a troco do salário, reduzindo-se o custo da mão de obra por unidade. O aumento da produtividade constituía, também, uma forma de lutar contra a escassez de mão de obra citada acima, tornando-se favorável à contenção dos salários reais. Foi nesse âmbito que surgiu a principal intervenção de F. W. Taylor ${ }^{7}$.

\section{Os escritos de F. W. Taylor a respeito do salário}

\subsection{Introdução}

F. W. Taylor teve uma vida profissional diretamente ligada à indústria. De maneira objetiva, sua atividade profissional visou a responder à necessidade que os dirigentes empresariais norte-americanos sentiam de aumentar a produtividade, nomeadamente, a da grande massa dos imigrantes sem experiência - significativa, ao menos - de trabalho na indústria.

As obras Shop management (1903) e Principles of scientific management (1911) refletem, de modo muito claro, sua experiência de vida e o objetivo primeiro de sua atividade profissional. Embora com forte caráter operacional, encontra-se nelas uma base ideológica explícita como, por exemplo, a apologia do corporativismo.

A existência de classes, definidas na essência pelo posicionamento diferente face à titularidade dos meios de produção e interesses estruturalmente antagônicos, constituem elementos-chave do pensamento marxista o qual, durante a vida de F. W. Taylor, já se divulgava nos meios sindicais do espaço euroatlântico. Nos EUA, os imigrantes de origem alemã constituíram-se como os principais difusores do pensamento marxista. Como resultado, em última instância, desse antagonismo de interesses, o funcionamento das sociedades em que existem classes assume permanentemente um caráter conflitante. Por causa de tais conflitos, há transformação social, isto é, o surgimento de formas de organização social mais eficientes. A luta de classes é, portanto, o motor da História.

A perspectiva de F. W. Taylor foi completamente diferente, visto ter afirmado de forma peremptória que era possível obter a máxima prosperidade para

(7) Principal, visto F. W. Taylor ter sido, também, um inventor patenteado. 
as duas partes: i) ao empresário que pretende reduzir o custo da mão de obra; ii) ao trabalhador que almeja um salário elevado:

...it is possible to give the workman what he most wants - high wages - and the employer what he wants - a low labor cost - for his manufactures (Taylor, 1911, p. 1)

Esta máxima prosperidade mútua substituiria o conflito entre as classes que ele presenciou ao longo da sua vida - por um esforço conjunto.

A palavra trabalhador, em F. W. Taylor, era sinônimo de trabalhador dedicado diretamente à produção material, portanto trabalhador manual. Ele considerou, implicitamente, as categorias profissionais intermédias como meras extensões da direção empresarial.

Finalmente, suas obras assumem um caráter extremamente afirmativo a respeito de temas complexos, relativos à natureza humana, que são debatidos há milênios, revelando, portanto, uma personalidade em que a dúvida tinha pouco espaço de manobra. Uma personalidade bem pouco científica.

Efetivamente, nota-se que F. W. Taylor assumiu, sem hesitação, que o ser humano em geral é avesso ao trabalho, preferindo a ociosidade ou, que os adultos, na relação com o trabalho, não passam de crianças crescidas ou, ainda, que o ser humano é egoísta. Ora, essas "certezas" foram os alicerces sobre os quais ele construiu sua obra.

\subsection{Os princípios científicos}

Então, que foi dito por F. W. Taylor?

O que o trabalhador mais pretende é um salário elevado. Essa pretensão é perfeitamente atendível por parte do dirigente da empresa, desde que haja o respeito por um conjunto de princípios os quais permitem aumentar a produção por trabalhador. Considerando-se a finalidade deste artigo, há quatro princípios expostos a seguir:

- Primeiro princípio: tarefas bem definidas para o trabalhador, com duração curta, individualizadas, que não sejam fáceis de executar ( large daily task).

Cada trabalhador deverá ter tarefas bem definidas para realizar em um tempo curto que terá de ser ainda mais curto quanto mais elementar for o intelecto do trabalhador. A esse respeito, F. W. Taylor estabeleceu a similitude com aquilo que faz o professor primário:

No efficient teacher would think of giving a class of students an indefinite lesson to learn. Each day a definite, clear-cut task is set by the teacher before each scholar, stating that he must learn just so much of the subject;... 
All of us are grown-up children, and it is equally true that the average workman will work with the greatest satisfaction, both to himself and to his employer, when he is given each day a definite task which he is to perform in a given time... (Taylor, 1911, p. 43).

Além disso, as tarefas não devem ser partilhadas. De modo excepcional, deverá haver trabalho em grupo, com divisão de ganho. É sua primeira investida contra o conceito social, sistematicamente entendido como maléfico para a produção, para cada trabalhador e para a sociedade. Refletindo sobre a experiência efetuada na Bethlehem Steel Company (Pennsylvania, EUA), afirmou:

It was arranged that as far as possible each laborer should be given a separate individual task.

$\cdots$

Each of these men was given a separate car to unload each day, and his wages depended upon his own personal work (Taylor, 1911, p. 20).

Only on few occasions, and then upon special permission, signed by the writer, were more than two men allowed to work on gang work, dividing their earnings between them. Gang work almost invariably results in a failing off in earnings and consequent dissatisfaction (Taylor, 1903, p. 17).

Generalizando, F. W. Taylor (1911) disse:

In dealing with workman under this type of management [scientific management], it is an inflexible rule to talk to and deal with only one man at a time, since each workman has his own special abilities and limitations... (Taylor, 1911, p. 7).

Importante salientar que, na época em que F. W. Taylor viveu, os fundadores da teoria econômica neoclássica ${ }^{8}$ haviam estabelecido claramente uma perspectiva atomística do ser humano enquanto agente econômico.

- Segundo princípio: condições estandardizadas até o mínimo pormenor (standard conditions) para o cumprimento das tarefas diárias, baseadas na análise científica do trabalho e não em regras empíricas decorrentes da experiência dos trabalhadores.

Há um método para se fazer o trabalho, o melhor de todos (one best method and best implement), que só pode ser determinado por meio da análise dos tempos e movimentos das tarefas laborais (time and motion study). Essa ideia tornou-se o ex libris da obra de F. W. Taylor. Complementarmente, deverá haver uma análise dos materiais e equipamentos utilizados.

(8) O inglês William Stanley Jevons (1835-1882), o francês Léon Walras (1834-1910) e o austríaco Carl Menger (1840-1921). 
A partir dessas análises, determina-se o salário correto do trabalhador. Sem elas, o custo da mão de obra será elevado e o salário, baixo:

Many of them [managers] are paying much higher prices per piece than are required to secure the maximum product while owing to a bad system, lack of exact knowledge of the time required to do work, and mutual suspicion and misunderstanding between employers and men, the output per man is so small that the men receive little if any more than average wages, both sides being evidently the losers thereby. The chief causes which produce this loss to both parties are: First (and the far most important), the profound ignorance of employers and their foremen as to the time in which various kinds of work should be done... (Taylor, 1903, p. 7).

Ora, segundo F. W. Taylor, o trabalhador não tem preparação inteletual e cultural para fazer tais análises, ou, se a tiver, não dispõe de tempo e meios para fazê-las. Finalmente, se dispuser de tudo isso, guardará suas descobertas para si a fim de utilizá-las para obter um acréscimo salarial.

A falta de tempo é particularmente notória, tendo em conta que o desenvolvimento da técnica aumentou muito o tempo necessário para levar a cabo a vertente intelectual do trabalho:

... because even if the workman was well suited to the development and use of scientific data, it would be physically impossible for him to work at his machine and at a desk at the same time (Taylor, 1911, p. 4-5).

Assim sendo, os ótimos métodos de realização do trabalho (materiais, equipamentos, tempos e movimentos) devem ser determinados por indivíduos destinados a essa função, ou seja, os membros do departamento de planejamento (planning department). A vertente intelectual do trabalho, portanto - até a dos chefes de equipe e dos capatazes (hoje, designados supervisores) - deve passar para o departamento de planejamento:

As far as possible the workmen, as well as the gang bosses and foremen, should be entirely relieved of the work of planning, and of all work which is more or less clerical in its nature. All possible brain work should be removed from the shop and centered in the planning or laying-out department, leaving for the foremen and gang bosses work strictly executive in its nature. Their duties should be to see that the operations planned and directed from the planning room are promptly carried out in the shop (Taylor, 1903, p. 35).

Por seu turno, para o departamento de planejamento determinar quanto trabalho diário poderá ser feito, há que dividir cada tarefa em elementos básicos/operações elementares, pôr um "trabalhador de eleição" (ou seja, um dos mais aptos em termos físicos e habilidade) a laborar no ritmo máximo e cronometrar, separadamente, cada um desses elementos básicos. Também, conferir 
tempos e ganhos salariais a cada operação elementar ao invés de fazer isso a toda a tarefa:

... the job should be subdivided into a number of divisions, and a separate time and price assigned to each division rather than to assign a single time and price for the whole job (Taylor, 1903, p. 29).

Como corolário desse princípio surge, portanto, a apologia da divisão do trabalho/especialização do trabalhador, alegando que aumenta a eficiência da atividade laboral. Dada a apologia da especialização funcional, até as funções do chefe de equipe, do supervisor (capataz) e dos membros do departamento de planejamento deverão ser divididas:

Throughout the whole field of management the military type of organization should be abandoned, and what may be called the "functional type" substituted in its place... If practicable the work of each man in the management should be confined to the performance of a single leading function (Taylor, 1903, p. 35).

- Terceiro princípio: escolha de "trabalhadores de eleição" para executar cada função profissional ${ }^{9}$.

O trabalho deverá ser feito pelos "trabalhadores de eleição" escolhidos entre os adequados para executar cada função. O conceito trabalhador adequado foi explicado nas seguintes passagens:

He [F. W. Taylor] would not for an instance advocate the use of a high-priced tradesman to do the work which could be done by a trained labourer or a lowerpriced man.

... each workman should be given as far as possible the highest grade of work for which his ability and physique fit him (Taylor, 1903, p. 6).

Ora, segundo F. W. Taylor, com o departamento de planejamento e a supervisão funcional, é possível colocar trabalhadores de menor qualificação (logo, mais baratos) em funções que antes eram atribuídas a outros mais qualificados (logo, mais caros). Os mais qualificados, que antes executavam tais funções, sobem, também, para outras mais qualificadas. Assim sendo, a divisão do trabalho não leva à desqualificação, mas, à qualificação:

It is true, for instance, that the planning room, and functional foremanship, render it possible for an intelligent laborer or helper in time to do much of the work now done by a machinist.

(9) Notar a seguinte passagem: L'ideale lavoristico che ha dominato il mondo occidentale, sino all'avvento del post-fordismo e del lavoro flessibile, è stato quello del lavoro vocato o lavoro vocazionale, secondo cui l'uomo possiede delle doti naturali in forza delle quali è "chiamato" a svolgere un'attività lavorativa determinata ed esclusiva per tutta la própria esistenza (Patriarchi, 2007, p. 61). 
... The machinist, with the aid of the new system, will rise to a higher class of work which he was unable to do in the past, and in addition, divided or functional foremanship will call for a larger number of men in this class, so that men, who must otherwise have remained machinists all their lives, will have the opportunity of rising to a foremanship (Taylor, 1903, p. 54-55).

Sendo, contudo, a organização piramidal, a lógica de raciocínio de F. W. Taylor faz com que o custo da mão de obra por unidade produzida seja menor, o que sintoniza muito bem com os objetivos dos empresários particularmente vivos na época em que ele escreveu, pelas razões já referidas.

- Quarto princípio: salário elevado em caso de cumprimento dos padrões de desempenho e saída, ao menos da função, em caso de seu não cumprimento.

É necessário elevar o salário em troca de aumento da produção individual, pois:

... first-class men are not only willing but glad to work at their maximum speed, providing they are paid from 30 to 100 per cent more than the average of their trade.

$\cdots$

Men will not work at their best unless assured a good liberal increase, which must be permanent (Taylor, 1903, p. 5-6).

Por que os trabalhadores só dão o seu melhor mediante incrementos liberais de salário? Segundo F. W. Taylor, tal fato provém de três causas. Afirmou que a primeira causa é a natureza do ser humano:

There is no question that the tendency of the average man (in all walks of life) is toward working at a slow, easy gait, and that it is only after a good deal of thought and observation on his part or as a result of example, conscience, or external pressure that he takes a more rapid pace (Taylor, 1903, p. 7).

A segunda causa resulta das relações interpessoais, pertencendo, portanto, ao domínio da psicologia social. É, uma vez mais, o caráter negativo do social:

This common tendency to "take it easy" is greatly increased by bringing a number of men together on a similar work and at a uniform standard rate of pay by the day.

Under this plan the better men gradually but surely slow down their gait to that of the poorest and least efficient. When a naturally energetic man works for a few days beside a lazy one, the logic of the situation is unanswerable: "Why should I work hard when that lazy fellow gets the same pay that I do and does only half as much work?" (Taylor, 1903, p. 7-8).

Ademais, essa junção de trabalhadores pagos de forma igual contribui para a insatisfação, formação de sindicatos e desencadear de greves: 
When employers herd their men together in classes, pay all of each class the same wages, and offer none of them any inducements to work harder or do better than the average, the only remedy for the men lies in combination; and frequently the only possible answer to encroachments on the part of their employers is a strike (Taylor, 1903, p. $69^{10}$ ).

Terceira causa: $O$ trabalho em ritmo inferior ao máximo possível acaba por dificultar que os dirigentes empresariais descubram o que fazer para os trabalhadores tornarem-se rápidos ao executar as tarefas. Devido a uma generalizada atitude errônea desses dirigentes, caso haja tal descoberta, tentarão utilizá-la para colocar os trabalhadores a operarem no ritmo máximo, sem acréscimo salarial ou com escasso acréscimo salarial.

Each workman soon finds out ... that when his employer is convinced that a man is capable of doing more work than he has done, he will find sooner or later some way of compelling him to do it with little or no increase of pay (Taylor, 1903, p. 8).

Assim sendo, para os trabalhadores operarem no ritmo máximo, a solução é pagar-lhes mais quando trabalham mais, demitir os que não cumprem padrões de desempenho e obter novos candidatos para substituírem os demitidos; substituição que será facilitada se as condições de trabalho forem altamente padronizadas e as funções profissionais basearem-se em tarefas simples e repetitivas - o que decorre da aplicação do segundo princípio enunciado.

Como corolário desse princípio, F. W. Taylor considerou o salário mínimo prejudicial, porque há trabalhadores com desempenho ruim que não merecem a remuneração especificada. Se tais trabalhadores tiverem de ser pagos pelo salário mínimo, os dirigentes empresariais serão obrigados a reduzir os salários dos melhores trabalhadores, a fim de ter uma massa salarial global que possibilite custos e preços competitivos:

Supposing a rule was made that no machinist should be paid less than $\$ 2.50$ per day. It is evident that if an employer were forced to pay $\$ 2.50$ per day to men who were only worth $\$ 1.50$ or $\$ 1.75$, in order to compete he would be obliged to lower the wages of those who in the past were getting more than $\$ 2.50$, thus pulling down the better workers in order to raise up the poorer men (Taylor, 1903, p. 71).

\subsection{Os supostos benefícios da gestão científica}

Considerando-se os quatro princípios citados, é possível haver sintonia com aquilo que F. W. Taylor denominou de gestão científica.

Desse modo, a mesma produção é efetuada por menos trabalhadores, portanto a redução da massa salarial daqui decorrente permitirá ao dirigente empresarial:

(10) F. W. Taylor cita um texto seu, datado de 1895. 
(1) Ter menor custo unitário de produção;

(2) Vender os produtos mais baratos, eventualmente, mais baratos do que os da concorrência;

(3) Aumentar o salário dos trabalhadores que continuarem ligados à empresa, talvez, acima do que é pago pela concorrência.

Eis como F. W. Taylor apresentou o resultado de sua intervenção na Bethlehem Steel Company como organizador da produção:

\begin{tabular}{|l|c|c|}
\hline & Old Plan & New Plan Task Work \\
\hline $\begin{array}{l}\text { The number of yard laborers was reduce } \\
\text { from between }\end{array}$ & $400 \& 600$ down to about & 140 \\
\hline Average number of tons per man per day & 16 & 59 \\
\hline Average earnings per man per day & $\$ 1.15$ & $\$ 1.88$ \\
\hline Average cost of handling a ton of $2240 \mathrm{lbs}$ & $\$ 0.072$ & $\$ 0.033$ \\
\hline
\end{tabular}

Fonte: Taylor (1911, p. 19).

Em outras palavras, as empresas que adotarem a gestão científica pagarão melhores salários e terão menor custo de mão de obra por unidade produzida. Desse modo, F. W Taylor demonstrou sua afirmação inicial de que é possível conciliar o interesse do trabalhador com o do empresário ${ }^{11}$.

Ademais, F. W. Taylor alargou o raciocínio para o exterior da fábrica, afirmando que a aplicação de suas ideias, ao traduzir-se em acréscimo da produtividade, teria um benefício social relevante:

... it is to the greater productivity of each individual that the whole country owes its greater prosperity...

$\cdots$

The general adoption of scientific management would readily in the future double the productivity of the average man engaged in industrial work... Think of the increase, both in the necessities and luxuries of life, which becomes available for the whole country... (Taylor, 1911, p. 52-53).

Tal raciocínio não está necessariamente correto. Como a prática social vem demonstrando, nada garante o mundo idílico perspectivado por F. W. Taylor, no qual:

The low cost of production which accompanies the doubling of the output will enable the companies that adopt this [scientific] management... to compete far better than they were able to before, and this will so enlarge their markets that their men will have almost constant work even in dull times... (Taylor, 1911, p. 53).

(11) Ver Taylor (1911, p. 1), anteriormente citado. 
Efetivamente, haverá trabalhadores dispensados na sequência do acréscimo de produtividade, sempre que o mesmo se efetuar em um ritmo superior ao da expansão da produção ${ }^{12}$. Se o fenômeno for extensivo à generalidade da economia, haverá desemprego ${ }^{13}$.

Se ficarem desempregados, quem lhes garante o tal acréscimo de bens necessários e supérfluos (the increase, both in the necessities and luxuries of life), ainda que sejam baratos? Havendo desemprego generalizado, quem garante sequer que os trabalhadores remanescentes terão aumento de salário como consequência do acréscimo de produtividade ${ }^{14}$ ? Realmente, tudo o mais constante, a existência de uma massa de desempregados funcionará como pressão no sentido da baixa do salário dos trabalhadores efetivos. Como, de maneira correta, afirmou Ernest Mandel, "As estatísticas e os estudos históricos demonstram-nos que todas as teorias que deduzem o nível dos salários diretamente do nível relativo de produtividade... não estão conformes com a realidade" (Mandel, 1962, p. 136) ${ }^{15}$.

Na época, no entanto, em que F. W. Taylor exerceu sua atividade profissional havia escassez de mão de obra, motivo que inviabilizou a utilização significativa do desemprego como fator de contenção salarial. Ele próprio afirmou: "There was such a demand for labor at the time that no workman was obliged to be out of work for more than a day or two..." (Taylor, 1903, p. 19).

\subsection{A forma do salário}

Segundo F. W. Taylor, como pagar?

O pagamento, para apresentar bons resultados, deverá ser feito imediatamente após o trabalho ter sido realizado. Poucos trabalhadores estão dispostos a esperar mais do que uma semana ou um mês para o receberem. O trabalhador médio deverá receber esse pagamento no final do dia:

(12) Ver Taylor (1911 - conteúdo do quadro da página 19, anteriormente citado), em que ele exemplificou como a aplicação de seu sistema conduziu à dispensa de trabalhadores (de 400-600 para 140).

(13) Mesmo que o fenômeno não seja extensivo à generalidade da economia, haverá desemprego caso não haja ajustamento da qualificação dos trabalhadores dispensados face à procura de mão de obra.

(14) Ver Taylor (1911 - conteúdo do quadro da página 19, anteriormente citado), em que ele exemplificou como a aplicação de seu sistema conduziu ao aumento do salário dos trabalhadores remanescentes (de $\$ 1,15$ para $\$ 1,88$ ).

(15) Mesmo que a pressão dos desempregados não tenha efeito sobre o salário nominal, terá efeito sobre a repartição do valor acrescentado. Em nossa tese de doutoramento sobre a banca comercial portuguesa, por exemplo, detectamos, para o período 1988-1999, não haver correlação positiva entre o produto bancário de exploração por trabalhador e a fatia dos custos com pessoal nesse produto bancário. Apenas em 1991-1993, os dois rácios tiveram evolução idêntica. 
A reward, if it is to be effective in stimulating men to do their best work, must come soon after the work has been done. But few men are able to look forward for more than a week or perhaps at most a month, and work hard for a reward which they are to receive at the end of this time.

The average workman must be able to measure what he has accomplished and clearly see his reward at the end of each day if he is to do his best (Taylor, 1911, p. 30).

Esse é um dos motivos pelos quais a repartição de lucros a favor dos trabalhadores no final do ano ou a entrega de ações tem resultados escassos. É que, para os trabalhadores, a vantagem do repouso hoje lhes parece superior à do trabalho árduo com eventual pagamento meses mais tarde:

The nice time which they are sure to have today if they take things easily and go slowly proves more attractive than steady hard work with possible reward to be shared with others six months later (Taylor, 1911, p. 31).

Ademais, a repartição equitativa de lucros ou ações não é um motivador equivalente ao ganho individualizado pois, conforme disse F. W. Taylor, "Personal ambition always has been and will remain a more powerful incentive to exertion than a desire for the general welfare" (Taylor, 1911, p. 31).

Em nenhuma de suas obras aceita, ao menos como hipótese, que a defesa dos interesses pessoais de cada trabalhador - a sua ambição pessoal, diria F. W. Taylor - possa passar pelo entendimento e ação coletiva, em um quadro de defesa do bem-estar geral, ou seja, que haja complementaridade entre ambição pessoal e bem-estar geral.

\subsection{A ciência da gestão: suposta base da harmonia social}

Por que motivo, então, trabalhadores e empresários desentendem-se a respeito do salário?

É relevante observar como F. W. Taylor opôs empresários e trabalhadores de base. Não há qualquer referência a conflitos entre empresários e as categorias profissionais intermédias (supervisores e departamento de planejamento).

O desentendimento advém, basicamente, de: i) os dirigentes empresariais querem que os trabalhadores ganhem menos do que os congêneres em outras empresas; ii) os trabalhadores querem, contrariamente, ganhar mais do que os congêneres noutras empresas:

It is safe to say that the majority of employers have a feeling of satisfaction when their workmen are receiving lower wages than those of their competitors. On the other hand very many workmen feel contented if they find themselves doing the same amount of work per day as other similar workmen do and yet are getting more pay for it (Taylor, 1903, p. 40). 
Disse então F. W. Taylor, em uma manifestação de cariz tecnocrático, sem dúvida, influenciada pelo tempo em que viveu que é a ciência da gestão (management) que tem a capacidade de resolver tal desentendimento:

The knowledge obtained from accurate time study for example, is a powerful implement, and can be used, in one case to promote harmony between the workmen and the management, by gradually educating, training and leading the workmen into new and better methods of doing the work... (Taylor, 1911, p. 49).

Aliás, o objetivo primordial da ciência da gestão é, precisamente, conciliar baixo custo da mão de obra com salários elevados e, por decorrência, empresários com trabalhadores:

The writer has already indicated that he thinks the first object in management is to unite high wages with a low labor cost (Taylor, 1903, p. 21).

Contraditoriamente, F. W. Taylor demonstrou clara consciência de que a ciência da gestão é passível de servir interesses sociais, afirmando que ela também pode ser utilizada para fazer os trabalhadores produzirem mais pelo mesmo ganho:

...or, in the other case, it [the knowledge obtained from accurate time study] may be used more or less as a club to drive the workmen into doing a larger day's work for approximately the same pay they received in the past (Taylor, 1911, p. 49).

Ter-lhe-á ocorrido, por exemplo, que os "pensadores" do departamento de planejamento, pressionados pelo dirigente empresarial, podem definir como ritmo de trabalho ótimo/tempo-padrão algo que é nitidamente inalcançável, ou quase, pelos trabalhadores?

Apesar disso, afirmou que não são os sindicatos e a contratação coletiva que conseguem estabelecer os salários adequados:

...the writer believes the system of regulating the wages and conditions of employment of whole classes of men by conference and agreement between the leaders of unions and manufacturers to be vastly inferior, both in its moral effect on the men and on the material interests of both parties, to the plan of stimulating each workman's ambition by paying him according to his individual worth, and without limiting him to the rate of work or pay of the average of his class (Taylor, 1903, p. $69^{16}$ ).

Afirmou F. W. Taylor que nem empresários nem trabalhadores percebem ser, para ambos, a contratação coletiva pior do que estimular cada trabalhador, dizendo-lhe que, se produzir mais, receberá mais ${ }^{17}$. Afirmou ainda que essa falta

(16) F. W. Taylor cita um texto seu, datado de 1895.

(17) Notar a seguinte passagem: "E così como Menenio Agrippa si sforzava di spiegare alla plebe romana - che era scesa in sciopero contro i patrizi - che il loro gesto minava la salute di quell'organismo vivente che è lo Stato, cosi Taylor ritiene che l'organizzazione scientifica del alvoro crei una tale 'armonia', che sia tanto intrinsecamente 'giusta', che gli operai non hanno necessità di ricorrere ad un atto violento - dai contorni quasi 'masochistici' - como lo sciopero. E anzi, ogni tentativo da parte di associazioni operaie di intervenire nell'impresa, magari per avanzare il problema della contrattazione collettiva; è considerata un 'interferenza', cioè un 'azione che altera l'equilibrio dell'organizzazione". (Patriarchi, 2007, p. 123). 
de percepção devia-se ao fato de ambas as partes ignorarem seus próprios interesses:

The chief reasons for this would seem to be a failure on the part of the workmen to understand the broad principles which affect their best interests as well as those of their employers. It is undoubtedly true, however, that employers as a whole are not much better informed or more interested in this matter than their workmen (Taylor, 1903, p. 69-70).

\section{Síntese e conclusão}

A obra de F. W. Taylor foi produto de um quadro histórico e de uma personalidade. Como quadro histórico, a vida econômica de seu tempo foi dominada pelo esforço acrescido dos dirigentes empresariais norte-americanos no sentido de conter os custos de produção por meio do desenvolvimento da técnica, da obtenção de economias de escala ou da redução do tempo de execução de trabalho.

F. W. Taylor teve uma ação relevante no que respeita ao último aspecto, procurando por essa via aumentar a produção efetuada em troca de um salário estipulado e, assim, reduzir o custo da mão de obra por unidade produzida. Segundo ele, esse aumento só seria possível mediante o cumprimento de um conjunto de princípios que intitulou de científicos:

- Tarefas ao trabalhador bem definidas, de curta duração, individualizadas e que não sejam de fácil execução (a large daily task);

- Condições estandardizadas nos mínimos detalhes (standard conditions), para o cumprimento das tarefas diárias, baseadas na análise científica do trabalho e não em regras empíricas decorrentes da experiência dos trabalhadores;

- Escolha de "trabalhadores de eleição" para executar cada função profissional;

- Salário elevado em caso de cumprimento dos padrões de desempenho; saída, ao menos da função, em caso de não cumprimento dos mesmos.

Segundo F. W. Taylor, do adequado cumprimento de tais princípios científicos resultariam, também, benefícios aos trabalhadores - no caso, salários elevados - e, assim sendo, afirmou a possibilidade de conciliar os interesses dos empresários com os dos trabalhadores.

Havendo benefícios mútuos, considerou que a renitência de ambas as partes em aceitar os princípios cientificos - fato a que ele assistiu durante a sua 
vida ${ }^{18}$ - apenas se justificava porque empresários e trabalhadores não tinham consciência perfeita dos respectivos interesses.

Conclui-se que, segundo F. W. Taylor, o estabelecimento de salários elevados resultará de uma associação da ciência da gestão, por via dos quatro princípios enunciados, com a consciência dos interesses de cada uma das partes envolvidas no processo produtivo: empresários e trabalhadores.

Que dizer, em termos conclusivos, dos escritos de F. W. Taylor a respeito da formação do salário?

Objetivamente, os mesmos resultam de uma visão simplista do ser humano/trabalhador, considerando-o como ente:

- Estruturalmente egoísta ${ }^{19}$;

- Avesso ao trabalho, atividade onde se rege pelo "take it easy"20;

- Com um funcionamento mental pouco elaborado, reduzido a um "grownup children", incapaz de esperar pelo pagamento do trabalho efetuado ${ }^{21}$ e que se satisfaz com funções cujo componente intelectual foi removido.

F. W. Taylor não admitiu - ao menos como hipótese - que poderia estar perante fenômenos decorrentes de uma determinada forma de organização social, portanto historicamente enquadrados.

Como corolário de sua perspectiva egoísta do ser humano, o conceito social foi encarado como negativo ao aumento da produção e formação de um salário elevado. Isso porque, quando o social prevalece, é apenas como fator gerador de perturbação do processo produtivo (menor produção, negociação coletiva, greves) e, por decorrência, prejudicial:

- Ao próprio trabalhador, porque recebe menor salário;

- À sociedade, porque recebe produtos a preço mais elevado.

Esse raciocínio está inquinado pois, goste-se ou não, a atividade produtiva e a formação do salário são fenômenos, sobretudo sociais e, como tal, têm de ser encarados, também, sob perspectiva macroscópica. Efetivamente,

(1) Não há leis naturais que determinem a formação do salário acima de seu limite fisiológico e os sindicatos constituem organizações que têm por objetivo a

(18) O que até levou o Senado dos EUA a investigar as consequências, para o bem-estar dos trabalhadores, da aplicação da teoria de F. W. Taylor.

(19) Ver Taylor (1911, p. 31), anteriormente citado.

(20) Ver Taylor (1903, p. 7-8), anteriormente citado

(21) Ver Taylor (1911, p. 30-31, 43), anteriormente citado. 
promoção dos interesses dos trabalhadores associados, nomeadamente no domínio salarial;

(2) O salário tem de ser encarado como categoria macroeconômica e não apenas como o que o trabalhador $x$ recebe;

(3) Igual a um dos possíveis corolários dos pontos anteriores, surge o salário mínimo - atacado por F. W. Taylor - como necessário para garantir um mínimo bem-estar social e atuar, positivamente, sobre a categoria macroeconômica consumo.

Nota-se que, objetivamente, sua defesa da atomização do processo produtivo, sob o pretexto do egoísmo do ser humano, opunha-se a um dos efeitos da acelerada concentração empresarial que caracterizou o seu tempo - o desenvolvimento da consciência de classe dos trabalhadores, consequentemente, de seu poder na sociedade ${ }^{22}$, com o inevitável impacto na formação do salário. Em contrapartida, tal defesa constituía um fator de acréscimo da intensidade do trabalho - até pelo estímulo ao surgimento de "trabalhadores de eleição" - com o inevitável impacto na repartição da riqueza criada a favor dos detentores do capital.

Por outro lado, no que diz respeito, especificamente, à aversão ao trabalho, em nenhuma de suas obras relata - ao menos como hipótese - que os trabalhadores possam sentir a respectiva atividade como algo estranho, um sacrifício para angariar a subsistência; portanto esse mesmo trabalhador que se arrasta durante oito horas na execução das suas tarefas poderá ser extremamente diligente em qualquer hobby ou ocupação que tenha em horário pós-laboral.

Nota-se que, baseado na visão do trabalhador como um ser indolente (inato e adiquirido por força das práticas laborais que F. W. Taylor considerava erradas), sua gestão científica - por via do segundo e quarto princípios enunciados - levava ao forte controle da atividade laboral, possibilitando o acréscimo da intensidade do trabalho.

E quanto ao primarismo mental? Ao afirmar que o trabalho desenrolavase de acordo com regras empíricas decorrentes da experiência dos trabalhadores, F. W. Taylor negou, de maneira implícita, a tese sobre o trabalhador enquanto ser mentalmente primário. Observa-se que, sob o pretexto do primarismo mental, sua gestão científica - por via do segundo princípio enunciado - levava a uma dicotomia no trabalho fabril que poupava dinheiro ao empresário: uma grande

(22) Como se constata, não é novidade o ataque ideológico e político aos sindicatos e à negociação coletiva a que, hoje, assistimos na Europa ocidental, tentando colocar o trabalhador isolado face à sua entidade patronal.

Economia e Sociedade, Campinas, v. 20, n. 2 (42), p. 397-415, ago. 2011. 
maioria minimamente qualificada, portanto de fácil substituição e mal paga face à sua produtividade versus uma pequena minoria bastante qualificada e bem paga.

Finalmente, se o primarismo mental e a aversão ao trabalho não impediam os trabalhadores de considerar, como seu principal objetivo, a obtenção de um salário elevado e, cumulativamente, se os princípios enunciados e postos em prática por F. W. Taylor conduziam a esse salário elevado, então por que o trabalho efetuado de acordo com os princípios propostos por ele foi tão detestado e contestado? Seria o fato de que os trabalhadores não tiveram consciência de seus interesses ? Que estranha força levaria tantos trabalhadores industriais dos EUA a não terem consciência de seu principal interesse? Será que, ao invés disso, os trabalhadores perceberam, de imediato, que o sistema de F. W. Taylor - além de psicologicamente danoso - conduzia, na prática, a uma desqualificação profissional (e humana) e a um acréscimo da intensidade do trabalho, levando, em última instância, a uma repartição da riqueza criada a favor dos detentores do capital $^{23}$ ?

Note-se que, quem tem o poder - o dirigente empresarial - tem, também, a suposta ciência da gestão a qual define as condições de pagamento. Assim sendo, que garantia há de que não usará essa suposta ciência, exclusiva ou essencialmente para benefício próprio, ou seja, para o aumento da taxa de lucro do negócio? A conversão à ideologia corporativista? Se a garantia for essa, a prática no tempo de F. W. Taylor demonstrou - e a prática atual continua a demonstrar - que a mesma é falsa.

\section{Referências bibliográficas}

BERNOUX, Philippe. La sociologie des organisations, ("points - essais"). 5. Ed. Paris: Éditions du Seuil, s. d. 382p.

GORZ, André. Técnicos, especialistas e luta de classes. In: AAVV. A divisão capitalista do trabalho. Lisboa: Iniciativas Editoriais, 1976. p. 219-268. (Colecção Século XX-XXI).

MANDEL, Ernest (1962). Traité d'économie marxiste. Tradução portuguesa de Nuno dos Santos. Tratado de economia marxista. Lisboa: Edições Delfos, 1975. p. 136.

ORTSMAN, Oscar (1978). Changer le travail - les expériences, les methodes, les conditions de l'expérimantation sociale. Tradução portuguesa, Mudar o trabalho - as experiências, os métodos, as condições de experimentação social. Lisboa: Fundação Calouste Gulbenkian, 1984. 410p.

PATRIARCHI, Adele. Il lavoro corroso - modernità, secolarizzazione, globalizzazione. Roma: Ediesse, 2007. p. 61, 123.

(23) O que desmente, na prática, o primarismo mental dos trabalhadores. 
PRADA, Valentin Vásquez de. História econômica mundial. Porto: Livraria Civilização Editora, s.d. 2 v. 520p. v. II. (Coleção Habitat).

PUGH, Derek S.; HICKSON, David J. Writers on organizations ("business/management"). 6. ed. London: Penguin Books, 2007. p.102-106.

SAINSAULIEU, Renaud. Sociologie de l'organisation et de l'entreprise. Paris: Presses de la Fondation Nationale des Sciences Politiques, 1987. 390p.

SILVA, Victor Paulo Gomes da. Estratégias empresariais e flexibilidade na gestão dos recursos humanos. Tese (Doutoramento em Gestão)-Universidade Aberta, Lisboa, 2001. p. 406-426.

TAYLOR, F. W. Shop management. p. 5-71. 1903. Disponível em: http://www.gutenberg.org/ratelimiter.php/dirs/etext04/shpmg10.txt. Acesso em: 25 dez. 2007.

. Principles of scientific management. p. 1-53. 1911. Disponível em: http://www.marxists.org/reference/subject/economics/taylor/principles/index.htm. Acesso em: 24 dez. 2007.

Economia e Sociedade, Campinas, v. 20, n. 2 (42), p. 397-415, ago. 2011. 